\title{
Consensus
}

Volume 21

Issue 1 Women and Men in Theological Education:

Article 22

Exploring the Present, Creating the Future

5-1-1995

\section{The New Genesis: Theology and the Genetic Revolution}

Richard C. Crossman

Follow this and additional works at: http://scholars.wlu.ca/consensus

\section{Recommended Citation}

Crossman, Richard C. (1995) "The New Genesis: Theology and the Genetic Revolution," Consensus: Vol. 21 : Iss. 1 , Article 22. Available at: http://scholars.wlu.ca/consensus/vol21/iss1/22

This Book Reviews is brought to you for free and open access by Scholars Commons @ Laurier. It has been accepted for inclusion in Consensus by an authorized editor of Scholars Commons @ Laurier. For more information, please contact scholarscommons@wlu.ca. 
conclusions (or premises) that it had not previously accepted or recognized" (p. 45). To accomplish this, it is necessary to start at some point(s) or measure of agreement, i.e., the place of identification. How can a theologian or preacher find this place, that is, how can they know to whom they are speaking? The audience, Cunningham observes, because it is part of the rhetorical process, is in fact constructed by the speaker. "Through the deployment of certain arguments, theologians are, in effect, saying: "this is what I want my audience to be; these are the kinds of people that I want them to become.' The traditional name for this activity is catechesis..." (p. 95).

Because this is a work in theological method advocating a rhetorical approach of persuasive argument, it forces the reader to engage the unfamiliar jargon of rhetoric. This task is not lightened by the author's peppering the text with Greek and Latin as well. Yet because it is this kind of work, it is as important to the preacher as to the theologian. No doubt a rhetorical critic who reads this review will detect that I am a homiletician! Which means that Cunningham has successfully constructed his audience to include not only Roman Catholic and Protestant theologians, but preachers as well!

Eduard R. Riegert

Waterloo Lutheran Seminary

\section{The New Genesis: Theology and the Genetic Revolu- tion}

Ronald Cole-Turner

Louisville, Kentucky: Westminster/John Knox Press, 1993 127 pages, $\$ 12.99$ U.S. paper

The genetic revolution is upon us whether we like it or not. Genetic engineering already is a powerful tool for healing, but this does not happen without also generating some significant concerns, ethically and theologically. Is this new found power something of which we should be wary? Or should we embrace it as a new God given way to participate with creation? Roland Cole-Turner chooses the latter approach in his book. However, he contends that we must understand this participation in a fuller and more adequate way than is often done today.

In describing this fuller and more adequate approach the author first provides the reader with a general summary of genetic developments from 1822 to the present. Then, placing this work within a broader cultural context (including theology), he argues that genetic engineering exists to "expand our ability to participate in God's work.... and thereby to glorify God."(p. 51) By this answer he means that 
Genetic engineering, when legitimated and limited by the Christian faith, would be used primarily to serve the needs of the weak, the sick, and the poor. This conviction should have a direct impact....so that the benefits of this technology will be readily available to those who need them most.(p.62)

Given this ethical stance, Cole-Turner then turns to the central concern of his book. After reviewing what a number of theologians and church bodies have said on the topic of genetic engineering, he notes that they focus almost exclusively on technology as a matter of co-creation or human cooperation in creation. This approach he finds to be too narrow because it generally begs the question of what the purpose of nature is in creation. Therefore the author declares that, with his book, he is

....trying to revise the idea of co-creation by proposing two major changes. The first of these is to insist....that creation be joined with redemption. The second change... is to call attention to the metaphor implicit in the idea of co-creation and to explore the logic of this metaphor more fully.(p. 103)

Regarding the first proposed change, he contends that a review of the traditional understanding of the Fall is needed. He asks whether it is "possible to understand the goodness and the disorder of nature in evolutionary terms, without a historic fall." (p. 81) He then outlines how he believes this is possible. In Cole-Turner's view, though technology and genetic engineering can produce ethically ambiguous situations, "This fact, however, should not keep us from seeking to serve God's redemptive purposes through our technology. It should serve rather as a humbling reminder that redemption must always be taking place in us even as it takes place through us." (p. 97)

Concerning the second proposed change, Cole-Turner urges that a more helpful approach to the matter of human cooperation in creation is to view technology (including genetic engineering) as a metaphor for God's creative activity. To call for a metaphorical understanding of God's engagement in genetic engineering means for the author:

- God seeks genetic change as a proper means of creative and redemptive activity.

- God works through natural processes to achieve genetic change.

- God works through humans to achieve intentional genetic change.

- The genetic engineering in which God engages, and to which our involvement should be limited, is that which is consistent with the nature and purposes of God the Creator and Redeemer, who renews the whole creation in anticipation of a new creation.(p. 109)

I found this book to be engaging and well written, despite the fact that the topic is a complex one. It succeeds in providing a good (though not always traditional) introduction to the area, especially as it relates to theology and Christian ethics. In reading the book, however, I would caution 
the reader to keep one thing in mind. While Roland Cole-Turner does acknowledge that the pursuit of new technology can be an ethically ambiguous activity, this caution ocassionally gets lost in the author's desire to affirm genetic engineering as a mode of God's creativity through humankind.

Nevertheless, I would recommend this book to anyone who wants to gain a general introduction to the topic. The author points to some very important concerns which will challenge us over the coming decades. Through his incisive summaries he provides the reader with a helpful doorway into the often confusing ethical dialogue surrounding genetic engineering. But most of all, his book demonstrates through its engagement with the topic of genetic engineering, that there exists a serious challenge for Christians. That is, Christians need to further develop a more adequate theology of healing, one that sees life as a whole and engages contemporary bioethical activities on an on-going basis.

Richard C. Crossman

Waterloo Lutheran Seminary

\section{This New Life Together: An Anthology of Wedding Meditations \\ Lima, OH: C.S.S. Publishing Co., Inc., 1994 \\ $63 \mathrm{pp}$.}

\section{The Word is Life: An Anthology of Funeral Medita- tions \\ Lima, OH: C.S.S. Publishing Co., Inc., 1994 \\ $74 \mathrm{pp}$.}

The publishing of either wedding or funeral sermons is rare and therefore much appreciated; homiletical and pastoral thanks are due to C.S.S. for presenting a volume of each!

The Foreword to each volume is by Michael L. Thompson, but he is not identified as the editor, nor is there any indication of how either anthology was composed. This seems to be part of general editorial carelessness at C.S.S.

Twenty-one wedding meditations are ostensibly offered-but three are not meditations at all: one is a marriage prayer (a good one!), one is a liturgical candle rite (it looks and sounds like a summary of something), one is a formula for a congregational pledge of support. One wonders where editorial control went! An ecumenical roster of preachers is represented, including one Roman Catholic. One meditation is for a Protestant-Catholic marriage; two are for older couples, both widowed; one is for a medical 